\title{
Switching from a traditional undergraduate programme in (clinical) pharmacology and therapeutics to a problem-based learning programme
}

\author{
David J. Brinkman $^{1,2}$ - Teresa Monteiro ${ }^{3}$ - Emilia C. Monteiro ${ }^{3} \cdot$ Milan C. Richir $^{1,2}$ - Michiel A. van Agtmael ${ }^{1,2}$. \\ Jelle Tichelaar ${ }^{1,2}$
}

Received: 26 April 2020 / Accepted: 15 October 2020 / Published online: 23 October 2020

(C) The Author(s) 2020

\begin{abstract}
Purpose The pharmacology and clinical pharmacology and therapeutics (CPT) education during the undergraduate medical curriculum of NOVA Medical School, Lisbon, Portugal, was changed from a traditional programme (i.e. discipline-based, lectures) to a problem-based learning (PBL) programme (i.e. integrated, case-based discussions) without an increase in teaching hours. The aim of this study was to investigate whether this change improved the prescribing competencies of final-year medical students.

Methods Final-year students from both programmes (2015 and 2019) were invited to complete a validated prescribing assessment and questionnaire. The assessment comprised 24 multiple-choice questions in three subdomains (working mechanism, sideeffects and interactions/contraindications), and five clinical case scenarios of common diseases. The questionnaire focused on self-reported prescribing confidence, preparedness for future prescribing task and education received.

Results In total, 36 (22\%) final-year medical students from the traditional programme and 54 (23\%) from the PBL programme participated. Overall, students in the PBL programme had significantly higher knowledge scores than students in the traditional programme (76\% (SD 9) vs 67\% (SD 15); $p=0.002$ ). Additionally, students in the PBL programme made significantly fewer inappropriate therapy choices $(p=0.023)$ and fewer erroneous prescriptions than did students in the traditional programme $(p=$ 0.27). Students in the PBL programme felt more confident in prescribing, felt better prepared for prescribing as junior doctor and completed more drug prescriptions during their medical training.

Conclusion Changing from a traditional programme to an integrated PBL programme in pharmacology and CPT during the undergraduate medical curriculum may improve the prescribing competencies of final-year students.
\end{abstract}

Keywords Clinical pharmacology $\cdot$ Therapeutics $\cdot$ Prescribing $\cdot$ Students $\cdot$ Undergraduate $\cdot$ Medical curriculum

David J. Brinkman and Teresa Monteiro contributed equally to this work.

Electronic supplementary material The online version of this article (https://doi.org/10.1007/s00228-020-03027-3) contains supplementary material, which is available to authorized users.

David J. Brinkman

d.brinkman@amsterdamumc.nl

1 Section Pharmacotherapy, Department of Internal Medicine, Amsterdam University Medical Centers, De Boelelaan 1117, 1081, HV Amsterdam, The Netherlands

2 Research and Expertise Center in Pharmacotherapy Education (RECIPE), Amsterdam, The Netherlands

3 Faculdade de Ciências Médicas, NOVA Medical School, Universidade NOVA de Lisboa, Lisbon, Portugal

\section{Introduction}

Medical graduates should be able to prescribe rationally (i.e. effectively, safely and at low cost), because after graduation they go directly into clinical practice and prescribe drugs on a daily basis, often with minimal supervision [1]. Poor prescribing may lead to prescribing errors and adverse drug events, which may cause prolonged hospital stays, unplanned hospital readmissions, significant morbidity and mortality and high healthcare costs [2, 3]. Unfortunately, a significant proportion of medical graduates seem not to have acquired sufficient knowledge, skills and attitudes required for rational prescribing $[1,4-6]$. This might be because of inadequate clinical pharmacology and therapeutics (CPT) education during the undergraduate medical curriculum. Indeed, most medical 
curricula in European medical schools devote little time to CPT education, which is still mainly based on traditional teaching/learning methods (e.g. self-study, lectures and written examinations) $[7,8]$. Compared with problem-based learning (PBL) methods, traditional methods seem to be associated with a lower level of prescribing knowledge and skills among medical students [1]. PBL is intended to simulate active learning and enables students to work together in groups and learn about a subject in the context of a real problem, such as casebased discussions [9]. Interest in PBL has increased over the last 30 years, and many PBL courses in CPT have been shown to increase the prescribing competence of medical students [10-25]. However, most of these studies evaluated the shortterm effect of a single course and very few evaluated the effect of an entire PBL programme on students' prescribing competence before they graduate.

In NOVA Medical School, Lisbon, Portugal, the pharmacology and CPT programme of the undergraduate medical curriculum underwent a major revision in 2011. The old discipline-based programme consisted of one course in basic pharmacology in the third year and one course in therapeutics in the fourth year (total of 144 teaching hours). The course in the third year was mainly based on traditional learning methods, such as lectures and written assessments, and that in the fourth year focused on learning about therapeutic guidelines and was managed by clinicians from various disciplines. In the new programme, pharmacology was integrated with pathophysiology, microbiology and neurosciences in the second and third years and a new course in CPT was introduced in the fifth year (total of 129 teaching hours). These courses are all based on the principles of PBL and focus on solving written patient cases in working groups under the supervision of clinical pharmacologists. The aim of this study was to determine whether these changes improved the prescribing competence of final-year medical students.

\section{Methods}

\section{Study design and participants}

The impact of a new programme in pharmacology and CPT was measured using an observational study with a pre/posttest design in two different cohorts of final-year medical students from NOVA Medical School. Differences between the old and the new programmes are shown in Table 1. The first group (historic control) included students who completed the traditional programme in 2015 and the second group (PBL group) included students who completed the new programme in 2019. Students were recruited by the local teacher during regular teaching sessions, by email and/or with announcements on electronic notice boards. Participation was voluntary, anonymous and without consequences to prevent test- driven learning prior to the assessment. All participants were asked to complete an online assessment and questionnaire just before graduation. The study was approved by the ethics committee of NOVA Medical School (process no. 64/2018/ CEFCM). Informed consent was obtained from all participants prior to inclusion.

\section{Study materials}

To evaluate prescribing knowledge and skills, we used a previously validated Web-based assessment tool and questionnaire [1]. The tool consisted of 24 multiple-choice questions (MCQs, knowledge) and five clinical case scenarios (skills). The MCQs covered three drug topics (i.e. mechanisms of action, side-effects and interactions and contraindications) and focused on the CPT knowledge that every medical graduate should have obtained before graduation (Supplementary Material A). The scenarios focused on essential diseases that medical graduates should know how to treat (i.e. essential hypertension, community-acquired pneumonia, acute bronchitis, osteoarthritis, gastroesophageal reflux) were presented in the same format, and were of comparable complexity (Supplementary material A). For each scenario, the student could choose to prescribe a new drug (maximum of two per scenario), not to prescribe any drug and/or to adapt current medication. If the student chose to prescribe a new drug, he/ she had to complete an electronic prescription form, including drug name, dose, dosage, route of administration and treatment duration.

The standardized questionnaire has been used in previous studies $[1,26]$ and asked questions about demographics, selfreported confidence in prescribing skills (WHO 6-step [27]), estimated number of drug prescriptions written during the undergraduate medical curriculum for training purposes, evaluation of CPT education received and perceived preparedness for prescribing.

\section{Data collection and scoring}

The assessment and questionnaire were completed by the historic control group in September 2015 and by the PBL group in June 2019. The assessment and questionnaire had to be completed within $60 \mathrm{~min}$ in a computer room at a scheduled time under the supervision of a local teacher. Prior to the assessment, all students were informed about the study objectives and received instructions. They were not allowed to use references or to consult each other, or the supervisor. The assessment was formative so that the results did not influence students' grades at the university. This was done to prevent test-driven learning prior to the assessment which could bias the outcomes.

All MCQs were scored as correct or incorrect. The case scenarios were scored within a month after the assessment 
Table 1 Differences in learning programmes

\begin{tabular}{ll}
\hline Traditional learning programme & Problem-based learning programme \\
\hline Discipline-based & Integrated \\
Before 2011 & After 2011 \\
Pharmacology 112 teaching hours & Pharmacology 99 teaching hours \\
CPT 32 teaching hours & CPT 30 teaching hours \\
Pharmacology ECTS 9 credits & Pharmacology ECTS 12 credits \\
CPT ECTS 3 credits & CPT ECTS 3 credits \\
Pharmacology one course in the third year & Pharmacology two courses in the second and third year \\
CPT one course in the fourth year & CPT one course in the fifth year \\
Teachers various clinicians & Teachers clinical pharmacologists \\
Teaching methods lectures & Teaching methods lectures and case-based working groups \\
Assessment methods MCQ exam & Assessment methods active participation in each \\
& teaching session, MCQ exam \\
\hline
\end{tabular}

$C P T$ clinical pharmacology and therapeutics, ECTS European Credit Transfer System, $M C Q$ multiple-choice question

according to a specifically designed scheme based on corresponding Portuguese and international guidelines applicable at the time (Table 2) [28-31]. A clinical pharmacologist with a medical background (D.B.) scored each treatment plan as being inappropriate, suboptimal or appropriate. Subsequently, the same person screened the drug prescriptions for prescribing errors, as classified by Dean et al. [32]. Errors found were categorized by type.

Table 2 Scoring categories for the treatment plans

\begin{tabular}{|c|c|c|}
\hline Category & Description & $\begin{array}{l}\text { Examples (pain } \\
\text { management of } \\
\text { osteoarthritis*) }\end{array}$ \\
\hline Appropriate & $\begin{array}{l}\text { A treatment plan was } \\
\text { considered appropriate if } \\
\text { it was complete, } \\
\text { effective, safe and low } \\
\text { cost according to } \\
\text { (inter)national guidelines }\end{array}$ & $\begin{array}{l}\text { Prescribing a NSAID and a } \\
\text { proton pump inhibitor to } \\
\text { a patient with a history of } \\
\text { a peptic ulcer and who } \\
\text { already uses } \\
\text { acetaminophen in } \\
\text { maximum dosage }\end{array}$ \\
\hline Suboptimal & $\begin{array}{l}\text { A treatment plan was } \\
\text { considered suboptimal if } \\
\text { it was just below the } \\
\text { standard of appropriate } \\
\text { (e.g. the dose of the drug } \\
\text { is slightly too high, less } \\
\text { recommended drug } \\
\text { choice) }\end{array}$ & $\begin{array}{l}\text { Prescribing codeine to a } \\
\text { patient with a history of a } \\
\text { peptic ulcer and who } \\
\text { already uses } \\
\text { acetaminophen in } \\
\text { maximum dosage }\end{array}$ \\
\hline Inappropriate & $\begin{array}{l}\text { A treatment plan was } \\
\text { considered inappropriate } \\
\text { if it was significantly } \\
\text { below the standard of } \\
\text { appropriate (e.g. } \\
\text { potentially harmful drug } \\
\text { interaction, relevant } \\
\text { contraindication) }\end{array}$ & $\begin{array}{l}\text { Prescribing a NSAID } \\
\text { without a proton pump } \\
\text { inhibitor to a patient with } \\
\text { a history of a peptic ulcer } \\
\text { and who already uses } \\
\text { acetaminophen in } \\
\text { maximum dosage }\end{array}$ \\
\hline
\end{tabular}

*Supplementary materials

\section{Data analysis}

Descriptive variables are expressed as percentages with associated ranges. The two groups were compared using MannWhitney for continuous data and a chi-square test for categorical data. The Spearman correlation coefficient $\left(r_{\mathrm{s}}\right)$ was used to analyse whether the number of drugs prescribed and selfrated confidence in prescribing was associated with skill scores. Knowledge scores were calculated as percentages of the maximum score. Data were collected in Excel format and analysed using IBM SPSS version 22.0 (IBM, Armonk, NY, USA). A $p$ value of $<0.05$ was considered significant.

\section{Results}

In total, 36 (22\%) final-year medical students from the traditional programme and 54 (23\%) final-year medical students from the PBL programme participated. Table 3 shows the characteristics of both groups. Students in the new programme were significantly older than students in the traditional programme (median 24 versus 23 years, $p=0.002$ ).

\section{Knowledge and skills}

Overall, students in the PBL programme had significantly higher knowledge scores than students in the traditional programme (mean $76 \%$ (SD 9) vs 67\% (SD 15); $p=0.002$ ). Also, students in the PBL programme had a significantly better knowledge of 'mechanisms of action' (90\% (SD 14) vs $81 \%$ (SD 17); $p=0.006$ ) and 'side-effects' (90\% (SD 12) vs $74 \%$ (SD 20); $p<0.001$ ). 'Interaction and contraindications' was the only drug topic for which scores were not significantly different between the two groups (48\% (SD 18) vs $45 \%$ (SD 22); $p=$ 0.62). Overall, students in the PBL programme made 
Table 3 Students' characteristics

\begin{tabular}{llll}
\hline & Traditional programme $n=36$ & PBL programme $n=54$ & $P$ value \\
\hline Age (median, range) & $23(22-34)$ & $24(23-41)$ & $0.002^{\mathrm{a}}$ \\
Sex (female, \%) & $56 \%$ & $72 \%$ & $0.10^{\mathrm{b}}$ \\
Portuguese nationality (\%) & $100 \%$ & $100 \%$ & \\
Year of start study (\%) & & & \\
2008 & $3 \%$ & - & \\
2009 & $17 \%$ & - & \\
2010 & $80 \%$ & - & \\
2012 & - & $5 \%$ & \\
2013 & - & $93 \%$ & \\
2014 & - & $2 \%$ & \\
\hline
\end{tabular}

$P B L$ problem-based learning

${ }^{a}$ Mann-Whitney

${ }^{\mathrm{b}}$ Chi-square

significantly fewer inappropriate therapy choices $(p=0.023)$ and fewer erroneous prescriptions than students in the traditional programme $(p=0.27)$ (Table 4). Therapy choices of both groups that were assessed as being 'potentially harmful' and 'potentially lethal' are described in detail in Supplementary Material B. The most common prescribing errors among both groups were 'incomplete/incorrect drug prescription', 'less effective drug choice' and 'overdosing' (Table 4).

\section{Attitudes}

Overall, students in the PBL programme felt significantly more confident in their prescribing skills than students in the traditional programme $(p<0.001$; Table 5$)$, especially regarding 'choose a (drug) treatment'. The only skill in which the students in the PBL programme did not feel more confident was 'verify the suitability of your drug treatment'. A larger proportion of students in the PBL programme felt adequately prepared for their prescribing responsibilities as a junior doctor compared with students in the traditional programme (21\% vs $9 \%$ ).

Most students in both the traditional and PBL programmes thought that too little time was devoted to clinical pharmacology ( $76 \%$ and $74 \%$, respectively) and therapeutics (88\% and $87 \%$, respectively). Similarly, a significant proportion of students in both the traditional and PBL programmes rated the clinical pharmacology (39\% and 51\%, respectively) and therapeutics education (55\% and 64\%, respectively) as poor or very poor. During undergraduate training, $49 \%$ of the students in the traditional programme did not complete any drug prescription as opposed to $23 \%$ of the students in the PBL programme.

\section{Associations}

Prescribing confidence was not associated with the prescribing skills scores of students in either the traditional programme ( $r=$
$0.20)$ or the PBL programme $(r=0.09)$. Similarly, the number of drug prescriptions was not strongly correlated with the skills scores of students in either the traditional programme $(r=0.21)$ or the PBL programme $(r=-0.01)$.

\section{Discussion}

This study shows that changing how pharmacology and CPT is taught, going from a traditional teaching programme to an integrated PBL programme, may increase prescribing competencies of final-year medical students. This effect was present even with a $10 \%$ decrease in the number of teaching hours. Students in the PBL programme had significantly better prescribing knowledge and skills than did students in the traditional programme. Additionally, they felt more confident in prescribing, felt better prepared for prescribing as junior doctor and completed more drug prescriptions during their medical training. However, since this is an observational study, our results should be interpreted with caution. Possible confounders such as increased awareness for pharmacotherapy in general over the last years, and CPT education in particular, and the increasing use of decision support systems might have influenced the results of the students in the PBL group. Nevertheless, results are in concordance with previous studies investigating the effect of PBL courses on prescribing knowledge, skills and attitudes of medical students [10-25]. Similarly, we previously showed that a context-learning programme for preclinical medical students, which is a more extreme form of PBL, leads to better prescribing during clinical clerkships [33]. However, this is one of the few studies to evaluate the effect of an entire PBL programme on students' prescribing competence before they graduate. Other studies mainly evaluated the short-term effect of a single PBL course in one study year. Similar to our previous study [1], we found 
Table 4 Skills of students in the traditional programme $(n=36)$ and problem-based learning programme $(n=54)$

\begin{tabular}{|c|c|c|c|}
\hline & $\begin{array}{l}\text { Traditional } \\
\text { programme } \\
N(\%)\end{array}$ & $\begin{array}{l}\text { PBL } \\
\text { programme } \\
N(\%)\end{array}$ & $\begin{array}{l}p \\
\text { value }\end{array}$ \\
\hline \multicolumn{4}{|l|}{ Therapy appropriateness } \\
\hline Total number of treatment plans & 169 & 270 & \\
\hline Median number of treatment plans per student (range) & $5(3-5)$ & $5(4-5)$ & \\
\hline Appropriate $^{\mathrm{a}}$ & $32(19)$ & $50(19)$ & \\
\hline Suboptimal $^{\mathrm{a}}$ & $32(19)$ & $82(30)$ & \\
\hline Inappropriate $^{\mathrm{a}}$ & $105(62)$ & $138(51)$ & $0.023^{\mathrm{b}}$ \\
\hline Not immediately harmful ${ }^{\mathrm{c}}$ & $88(84)$ & $135(99)$ & \\
\hline Potentially harmful ${ }^{\mathrm{c}}$ & $12(11)$ & $3(1)$ & \\
\hline Potentially lethal $^{\mathrm{c}}$ & $5(5)$ & 0 & \\
\hline \multicolumn{4}{|l|}{ Prescriptions } \\
\hline Total number of drug prescriptions & 197 & 382 & \\
\hline $\begin{array}{l}\text { Median number of drug prescriptions per student } \\
\text { (range) }\end{array}$ & $7(4-10)$ & $7(5-10)$ & \\
\hline Total number of prescribing errors & 260 & 453 & \\
\hline Number of drug prescriptions including errors & $160(81)$ & $288(75)$ & $0.27^{\mathrm{d}}$ \\
\hline \multicolumn{4}{|l|}{ Types of errors ${ }^{\mathrm{e}}$} \\
\hline Drug not indicated or inappropriate for indication & $29(11)$ & $19(4)$ & \\
\hline Less effective drug choice & $64(25)$ & $56(13)$ & \\
\hline Underdosing & $20(8)$ & $56(13)$ & \\
\hline Overdosing & $28(11)$ & $63(14)$ & \\
\hline Too short duration & $0(0)$ & $20(4)$ & \\
\hline Too long duration & $15(6)$ & $63(14)$ & \\
\hline Undefined duration & $2(1)$ & $29(6)$ & \\
\hline Incorrect drug form & $0(0)$ & $4(1)$ & \\
\hline Incomplete/incorrect drug prescription & $93(36)$ & $124(27)$ & \\
\hline Protecting medication omitted & $6(2)$ & $12(3)$ & \\
\hline Inappropriate abbreviation & $0(0)$ & $0(0)$ & \\
\hline Therapeutic duplicity & $0(0)$ & $2(0)$ & \\
\hline Drug group name & $3(1)$ & $4(1)$ & \\
\hline Other & $0(0)$ & $1(0)$ & \\
\hline
\end{tabular}

$P B L$ problem-based learning

${ }^{\text {a }}$ Percent of total number of treatment plans

${ }^{\mathrm{b}}$ Chi-square test

${ }^{\mathrm{c}}$ Percent of total number of inappropriate treatment plans

d Mann-Whitney

${ }^{\mathrm{e}}$ Percent of the total number of prescribing errors an increase in knowledge among students in the PBL programme, even though PBL is often said to lead to less factual knowledge in the basic sciences, such as pharmacology [34]. This might be explained by the fact that PBL is superior to traditional teaching methods in terms of long-term knowledge retention and the application of knowledge [35].

Our results suggest that integrating PBL modules in CPT education throughout the medical curriculum is associated with an increase in students' prescribing competence at the end of the medical curriculum. Interestingly, the total number of CPT teaching hours was $10 \%$ lower in the PBL programme than in the traditional programme (129 vs $144 \mathrm{~h}$ ), which suggests that the content and context of teaching are probably more important than the number of teaching hours. Nevertheless, the integration of training sessions throughout the medical curriculum can be challenging for medical schools with few CPT teachers. In order to reduce the workload of teachers, the Education Working Group of the European Association for Clinical Pharmacology and Therapeutics (EACPT) recommends near-peer teaching and the use of 
Table 5 Self-rated confidence (WHO 6-step) of students in the traditional programme $(n=36)$ and problem-based learning programme $(n=54)$

\begin{tabular}{lll}
\hline WHO 6-step & $\begin{array}{l}\text { Traditional programme } \\
(\max 5 ; \pm \mathrm{SD})\end{array}$ & $\begin{array}{l}\text { PBL programme } \\
(\max 5 ; \pm \mathrm{SD})\end{array}$ \\
\hline Step 1: define indication & $3.1 \pm 0.8$ & $3.4 \pm 0.9$ \\
Step 2: specify therapeutic objective & $2.9 \pm 0.9$ & $3.4 \pm 0.9$ \\
Step 3a: specify standard treatment & $2.7 \pm 1.0$ & $3.3 \pm 0.8$ \\
Step 3b: verify the suitability of your treatment & $2.6 \pm 1.0$ & $2.4 \pm 0.9$ \\
Step 4a: choose a (drug) treatment & $2.3 \pm 0.8$ & $3.0 \pm 1.0$ \\
Step 4b: choose the correct dose and interval & $1.6 \pm 0.7$ & $2.1 \pm 1.0$ \\
Step 4c: calculate the correct drug dose & $1.8 \pm 0.8$ & $2.4 \pm 1.1$ \\
Step 5a: write a drug prescription & $2.5 \pm 1.0$ & $2.9 \pm 0.9$ \\
Step 5b: give information and instructions & $2.6 \pm 1.0$ & $3.2 \pm 0.8$ \\
Step 6: determine monitoring parameters & $2.6 \pm 0.8$ & $2.8 \pm 0.8$ \\
Total & $\mathbf{2 . 5} \pm \mathbf{0 . 5}$ & $\mathbf{2 . 9} \pm \mathbf{0 . 5}$ \\
\hline
\end{tabular}

$P B L$ problem-based learning

${ }^{\mathrm{a}}$ Mann-Whitney online learning resources, such as E-learning and Ebooks [8].

Despite an improvement in skills, a large proportion (51\%) of the treatment plans of students in the PBL programme were still inappropriate (although not immediately harmful), and many drug prescriptions contained errors. This might be because although students learned to solve written patient cases, they received little practical teaching in simulated and real-life practice settings, as evidenced by the finding that only $23 \%$ of the students in the PBL programme had written out a prescription before they graduated.

A large proportion of students in the PBL programme still felt that they were not adequately prepared for their prescribing role and were not satisfied about the quantity and quality of CPT education. To further improve pharmacology and CPT education, we have the following recommendations, which are in line with those of the EACPT [36]. First, it is important that CPT is a clear and visible programme integrated longitudinally throughout the entire medical curriculum, starting as early as possible. In most European medical schools, CPT is taught in one or two separate courses and still accounts for a relatively small proportion of the total study load of the entire curriculum (1\%) [8]. Second, to further improve students' skills, it is essential that they take part in role-playing sessions with simulated patients and write drug prescriptions for real patients during clinical clerkships, under supervision of an experienced clinician. Third, it is also important that learning outcomes are compatible with the learning environment and assessment activities throughout the medical curriculum (constructive alignment). For example, skills should not be assessed with MCQs but with Objective Structured Clinical Examinations (OSCE) and workplace-based assessments [8]. Fourth, a valid and reliable prescribing assessment at or near the end of the curriculum is necessary to demonstrate that medical graduates have achieved the necessary competence to prescribe rationally. Unlike Portugal, some European countries such as the UK and the Netherlands already implemented such an assessment at a national level [37, 38]. In the UK, the Prescribing Safety Assessment (PSA) has shown to be feasible with the majority of final-year medical students meeting the prespecified standard of prescribing competence [37, 38]. A new Erasmus+ project is currently underway to develop, test and implement a standardised assessment on safe prescribing (EUroPE+) during the undergraduate medical curriculum in the European Union (EU) [39].

Although there was some improvement, students in both groups had a poor knowledge of drug interactions and contraindications $(<50 \%$ score $)$ and did not feel confident in verifying the suitability of their treatment choice, as has also been found in other studies $[1,26]$. One could question whether it is necessary that students have this knowledge because most electronic prescribing systems alert doctors to potentially harmful drug combinations and contraindications. However, prescribing systems often provide a high volume of irrelevant drug safety alerts, which could lead to 'alert fatigue' [40]. Additionally, the alerts provided by electronic prescribing systems have to be interpreted in the context of the specific patient; some alerts may be applicable, or not applicable, at the individual level. For these reasons, medical students should not reply to heavily on these decision support systems but learn to check the suitability of their drug choice for the specific patient context and know relevant drug interactions and contraindications by heart.

The finding that self-rated prescribing confidence was not strongly associated with assessed skills has been reported previously [26] and indicates that medical students do not accurately assess their prescribing skills. Since both lack of confidence and overconfidence might be harmful for patients, educational programmes should allow for discussion of this lack of self-knowledge with medical students. 
Our study should be interpreted in the light of some limitations. First, this was an observational study with a historic control rather than a randomized controlled trial; however, because of practical reasons, it was not possible to withhold the PBL programme from any group of students. Second, the response rate of the participating students was very low; therefore, findings cannot be generalizable to the entire cohort. Despite the low response rate, the knowledge and skills of participating students might have been overestimated because students who participate voluntary are probably more motivated than average. Indeed, a recent study showed that students who participated in a non-mandatory pharmacology sessions were more likely to pass the final course exam than those who did not [41]. Third, the fact that students were not allowed to use references during the assessment differs from clinical practice in which they are allowed to do so. This may have negatively influenced students' competencies. However, in clinical practice, doctors do not always have time to refer to relevant prescribing guidelines. Prescribing in these or acute situations is a reason why doctors should have ready knowledge and a broad skills set for common clinical problems. Fourth, the study was conducted in one medical school, which limits the generalizability of our results to other faculties and countries. Fifth, the fact that the therapeutics plans were reviewed by only one assessor limits the reliability of our results. Lastly, because the assessment was performed in a controlled environment, it can be questioned whether the same results would be found in daily clinical practice with all its attendant distractions.

\section{Conclusion}

Taking the above limitations into account, we conclude that switching from a traditional programme to an integrated PBL programme with fewer teaching hours to teach pharmacology and CPT may be associated with increase in prescribing competencies among final-year medical students. Since prescribing skills were still not satisfactory, more attention should be given to training and explicitly assessing these skills in a simulated or clinical setting. In the future, it would be interesting to study the effect of an undergraduate PBL programme in larger cohorts and on the prescribing competence of junior doctors.

Acknowledgements We are grateful to all medical students who participated in this study.

Authors' contributions DB, MR, MvA and JT conceived and designed the study. TM and EM performed the data collection. DB analysed and interpreted the data. DB and TM prepared the manuscript. All authors revised the manuscript for important intellectual content and approved the final version.
Funding This research received funding from the European Association for Clinical Pharmacology and Therapeutics (EACPT).

Data availability The data that support the findings of this study are available on request from the corresponding author.

\section{Compliance with ethical standards}

Conflict of interest The authors declare that they have no conflict of interest.

Ethics approval and consent to participate The ethics committee of NOVA Medical School, Lisbon, Portugal, approved the study (process no. $64 / 2018 /$ CEFCM).

\section{Consent for publication Not applicable.}

Code availability Not applicable.

Open Access This article is licensed under a Creative Commons Attribution 4.0 International License, which permits use, sharing, adaptation, distribution and reproduction in any medium or format, as long as you give appropriate credit to the original author(s) and the source, provide a link to the Creative Commons licence, and indicate if changes were made. The images or other third party material in this article are included in the article's Creative Commons licence, unless indicated otherwise in a credit line to the material. If material is not included in the article's Creative Commons licence and your intended use is not permitted by statutory regulation or exceeds the permitted use, you will need to obtain permission directly from the copyright holder. To view a copy of this licence, visit http://creativecommons.org/licenses/by/4.0/.

\section{References}

1. Brinkman DJ, Tichelaar J, Schutte T, Benemei S, Böttiger Y, Chamontin B, Christiaens T, Likic R, Ma iulaitis R, Marandi T, Monteiro EC, Papaioannidou P, Pers YM, Pontes C, Raskovic A, Regenthal R, Sanz EJ, Tamba BI, Wilson K, Vries TP, Richir MC, Agtmael MA, on behalf of the Working Group Research on CPT Education of the European Association for Clinical Pharmacology and Therapeutics (EACPT) (2016) Essential competencies in prescribing: a first European cross-sectional study among 895 finalyear medical students. Clin Pharmacol Ther 101:281-289. https:// doi.org/10.1002/cpt.521

2. Dean B, Schachter M, Vincent C, Barber N (2002) Prescribing errors in hospital inpatients: their incidence and clinical significance. Qual Saf Health Care 11:340-344. https://doi.org/10.1136/ qhe. 11.4.340

3. Ashcroft DM, Lewis PJ, Tully MP, Farragher TM, Taylor D, Wass V, Williams SD, Dornan T (2015) Prevalence, nature, severity and risk factors for prescribing errors in hospital inpatients: prospective study in 20 UK hospitals. Drug Saf 38:833-843. https://doi.org/10. 1007/s40264-015-0320-x

4. Heaton A, Webb DJ, Maxwell SRJ (2008) Undergraduate preparation for prescribing: the views of 2413 UK medical students and recent graduates. Br J Clin Pharmacol 66:128-134. https://doi.org/ 10.1111/j.1365-2125.2008.03197.x

5. Lempp H, Seabrook M, Cochrane M, Rees J (2005) The transition from medical student to doctor: perceptions of final year students and preregistration house officers related to expected learning 
outcomes. Int J Clin Pract 59:324-329. https://doi.org/10.1111/j. 1742-1241.2005.00438.x

6. Dornan T, Ashcroft D, Heathfield H, et al (2009) An indepth investigation into causes of prescribing errors by foundation trainees in relation to their medical education: EQUIP study. http://www. gmc-uk.org/FINAL_Report_prevalence_and_causes_of prescribing_errors.pdf_28935150.pdf. Accessed 20 February $\overline{2} 02 \overline{0}$

7. Orme M, Sjoqvist $\bar{F}$, Bircher J, Bogaert M, Dukes MNG, Eichelbaum M, Gram LF, Huller H, Lunde I, Tognoni G (1990) The teaching and organisation of clinical pharmacology in European medical schools (W.H.O. Working Group on Clinical Pharmacology). Eur J Clin Pharmacol 38(2):101-105. https://doi. org/10.1007/bf00265965

8. Brinkman DJ, Tichelaar J, Okorie M, Bissell L, Christiaens T, Likic R, Mačìulaitis R, Costa J, Sanz EJ, Tamba BI, Maxwell SR, Richir MC, van Agtmael M, for the Education Working Group of the European Association for Clinical Pharmacology and Therapeutics (EACPT) (2017) Pharmacology and therapeutics education in the European Union needs harmonization and modernization: a cross-sectional survey among 185 medical schools in 27 countries. Clin Pharmacol Ther 102:815-822. https://doi.org/10. $1002 /$ cpt.682

9. Wood DF (2003) Problem based learning. BMJ 326:328-330. https://doi.org/10.1136/bmj.326.7384.328

10. Akici A, Kalaca S, Goren MZ et al (2004) Comparison of rational pharmacotherapy decision-making competence of general practitioners with intern doctors. Eur J Clin Pharmacol 60:75-82. https://doi.org/10.1007/s00228-004-0751-2

11. de Vries TP (1993) Presenting clinical pharmacology and therapeutics: evaluation of a problem based approach for choosing drug treatments. Br J Clin Pharmacol 35:591-597. https://doi.org/10. 1111/j.1365-2125.1993.tb04187.x

12. de Vries TP, Henning RH, Hogerzeil HV et al (1995) Impact of a short course in pharmacotherapy for undergraduate medical students: an international randomised controlled study. Lancet 346: 1454-1457. https://doi.org/10.1016/S0140-6736(95)92472-8

13. Hassan NA, Abdulla AA, Bakathir HA, Al-Amoodi AA, Aklan AM, de Vries TP (2000) The impact of problem-based pharmacotherapy training on the competence of rational prescribing of Yemen undergraduate students. Eur J Clin Pharmacol 55:873876. https://doi.org/10.1007/s002280050710

14. Scobie SD, Lawson M, Cavell G, Taylor K, Jackson SH, Roberts TE (2003) Meeting the challenge of prescribing and administering medicines safely: structured teaching and assessment for final year medical students. Med Educ 37:434-437. https://doi.org/10.1046/j. 1365-2923.2003.01492.x

15. Vollebregt JA, Metz JC, de Haan M, Richir MC, Hugtenburg JG, de Vries TP (2006) Curriculum development in pharmacotherapy: testing the ability of preclinical medical students to learn therapeutic problem solving in a randomized controlled trial. Br J Clin Pharmacol 61:345-351. https://doi.org/10.1111/j.1365-2125.2005. 02571.x

16. Garbutt JM, DeFer TM, Highstein G, McNaughton C, Milligan P, Fraser VF (2006) Safe prescribing: an educational intervention for medical students. Teach Learn Med 18:244-250. https://doi.org/10. 1207/s15328015tlm1803_10

17. Karaalp A, Akici A, Kocabasoglu YE, Oktay S (2003) What do graduates think about a two-week rational pharmacotherapy course in the fifth year of medical education? Med Teach 25:515-521. https://doi.org/10.1080/014215903100100418

18. Wells JL, Borrie MJ, Crilly R, Brymer CD, Hurwitz JS (2002) A novel clinical pharmacy experience for third-year medical students. Can J Clin Pharmacol 9:7-16

19. Celebi N, Weyrich P, Riessen R, Kirchhoff K, LammerdingKoppel M (2009) Problem-based training for medical students reduces common prescription errors: a randomised controlled trial.
Med Educ 43:1010-1018. https://doi.org/10.1111/j.1365-2923. 2009.03452.x

20. Sandilands EA, Reid K, Shaw L, Bateman DN, Webb DJ, Dhaun N, Kluth DC (2011) Impact of a focussed teaching programme on practical prescribing skills among final year medical students. $\mathrm{Br} \mathrm{J}$ Clin Pharmacol 71:29-33. https://doi.org/10.1111/j.1365-2125. 2010.03808.x

21. Al Khaja KA, Handu SS, James H, Mathur VS, Sequeira RP (2005) Assessing prescription writing skills of pre-clerkship medical students in a problem-based learning curriculum. Int J Clin Pharmacol Ther 43:429-435. https://doi.org/10.5414/cpp43429

22. Al Khaja KA, James H, Sequeira RP (2013) Effectiveness of an educational intervention on prescription writing skill of preclerkship medical students in a problem-based learning curriculum. J Clin Pharmacol 53:483-490. https://doi.org/10.1002/jcph.68

23. Guney Z, Uluoglu C, Yucel B, Coskun O (2009) The impact of rational pharmacotherapy training reinforced via prescription audit on the prescribing skills of fifth-year medical students. Int J Clin Pharmacol Ther 47:671-678. https://doi.org/10.5414/cpp47671

24. Zgheib NK, Simaan JA, Sabra R (2011) Using team-based learning to teach clinical pharmacology in medical school: student satisfaction and improved performance. J Clin Pharmacol 51:1101-1111. https://doi.org/10.1177/0091270010375428

25. Tichelaar J, van Kan C, van Unen RJ, Schneider AJ, van Agtmael MA, de Vries TPGM, Richir MC (2015) The effect of different levels of realism of context learning on the prescribing competencies of medical students during the clinical clerkship in internal medicine: an exploratory study. Eur J Clin Pharmacol 71:237242. https://doi.org/10.1007/s00228-014-1790-y

26. Brinkman DJ, Tichelaar J, van Agtmael MA, de Vries TP, Richir MC (2015) Self-reported confidence in prescribing skills correlates poorly with assessed competence in fourth-year medical students. $\mathrm{J}$ Clin Pharmacol 55:825-830. https://doi.org/10.1002/jcph.474

27. de Vries TP, Henning RH, Hogerzeil HV, Fresle DA (1994) Guide to good prescribing. World Health Organisation, Geneva

28. Mancia G, Fagard R, Narkiewicz K, Redon J, Zanchetti A, Böhm M, Christiaens T, Cifkova R, de Backer G, Dominiczak A, Galderisi M, Grobbee DE, Jaarsma T, Kirchhof P, Kjeldsen SE, Laurent S, Manolis AJ, Nilsson PM, Ruilope LM, Schmieder RE, Sirnes PA, Sleight P, Viigimaa M, Waeber B, Zannad F, Redon J, Dominiczak A, Narkiewicz K, Nilsson PM, Burnier M, Viigimaa M, Ambrosioni E, Caufield M, Coca A, Olsen MH, Schmieder RE, Tsioufis $\mathrm{C}$, van de Borne $\mathrm{P}$, Zamorano JL, Achenbach S, Baumgartner H, Bax JJ, Bueno H, Dean V, Deaton C, Erol C, Fagard R, Ferrari R, Hasdai D, Hoes AW, Kirchhof P, Knuuti J, Kolh P, Lancellotti P, Linhart A, Nihoyannopoulos P, Piepoli MF, Ponikowski P, Sirnes PA, Tamargo JL, Tendera M, Torbicki A, Wijns W, Windecker S, Clement DL, Coca A, Gillebert TC, Tendera M, Rosei EA, Ambrosioni E, Anker SD, Bauersachs J, Hitij JB, Caulfield M, de Buyzere M, de Geest S, Derumeaux GA, Erdine S, Farsang C, Funck-Brentano C, Gerc V, Germano G, Gielen S, Haller H, Hoes AW, Jordan J, Kahan T, Komajda M, Lovic D, Mahrholdt H, Olsen MH, Ostergren J, Parati G, Perk J, Polonia J, Popescu BA, Reiner Z, Rydén L, Sirenko Y, Stanton A, Struijker-Boudier H, Tsioufis C, van de Borne P, Vlachopoulos C, Volpe M, Wood DA (2013) 2013 ESH/ESC guidelines for the management of arterial hypertension: the task force for the management of arterial hypertension of the European Society of Hypertension (ESH) and of the European Society of Cardiology (ESC). Eur Heart J 34:2159-2219. https://doi.org/10.1093/ eurheartj/eht151

29. World Health Organisation (1996) Cancer pain relief: with a guide to opioid availability. http://apps.who.int/iris/bitstream/10665/ 37896/1/9241544821.pdf. Accessed 20 February 2020

30. European Medicines Agency (2011) Guideline on the evaluation of drugs for the treatment of gastro-oesophageal reflux disease. http:// 
www.ema.europa.eu/docs/en_GB/document_library/Scientific guideline/2011/03/WC500103307.pdf. Accessed 20 February 2020

31. Médicos do Sistema Nacional de Saúde (2011) Antibioterapia na Pneumonia Adquirida na Comunidade em Adultos Imunocompetentes. https://www.dgs.pt/directrizes-da-dgs/normase-circulares-normativas/norma-n-0452011-de-26122011-jpg.aspx. Accessed 20 February 2020

32. Dean B, Barber N, Schachter M (2000) What is a prescribing error? Qual Health Care 9:232-237. https://doi.org/10.1136/qhc.9.4.232

33. Richir MC, Tichelaar J, Stam F, Thijs A, Danner SA, Schneider AJ, de Vries TPGM (2008) A context-learning pharmacotherapy program for preclinical medical students leads to more rational drug prescribing during their clinical clerkship in internal medicine. Clin Pharmacol Ther 84:513-516. https://doi.org/10.1038/clpt.2008.82

34. Vernon DT, Blake RL (1993) Does problem-based learning work? A meta-analysis of evaluative research. Acad Med 68:550-563. https://doi.org/10.1097/00001888-199307000-00015

35. Yew EHJ, Goh K (2016) Problem-based learning: an overview of its process and impact on learning. Health Prof Educ 2:75-79

36. Brinkman DJ, Tichelaar J, Mokkink LB, Christiaens T, Likic R, Maciulaitis R, Costa J, Sanz EJ, Maxwell SR, Richir MC, van Agtmael MA, the Education Working Group of the European Association for Clinical Pharmacology and Therapeutics (EACPT) and its affiliated Network of Teachers in Pharmacotherapy (NOTIP) (2018) Key learning outcomes for clinical pharmacology and therapeutics in Europe: a modified Delphi study. Clin Pharmacol Ther 104:317-325. https://doi.org/10.1002/ cpt.962

37. Kramers C, Janssen BJ, Knol W, Hessel MHM, Mulder WM, Dumont G, Maassen van den Brink A, Tichelaar J (2017) A license to prescribe. Br J Clin Pharmacol 83:1860-1861. https://doi.org/10. 1111/bcp.13257

38. Maxwell SR, Coleman JJ, Bollington L, Taylor C, Webb DJ (2017) Prescribing safety assessment 2016: delivery of a national prescribing assessment to $7343 \mathrm{UK}$ final-year medical students. Br J Clin Pharmacol 83:2249-2258. https://doi.org/10.1111/bcp.13319

39. European Prescribing License: Preparing future medical doctors in the European Union for safe prescribing (2019) https://ec.europa. eu/programmes/erasmus-plus/projects/eplus-project-details/\# project/2019-1-NL01-KA203-060492. Accessed 14 July 2020

40. Metzger J, Welebob E, Bates DW, Lipsitz S, Classen DC (2010) Mixed results in the safety performance of computerized physician order entry. Health Aff (Millwood) 29:655-663. https://doi.org/10. 1377/hlthaff.2010.0160

41. Carlsson T, Winder M, Eriksson AL, Wallerstedt SM (2020) Student characteristics associated with passing the exam in undergraduate pharmacology courses - a cross-sectional study in six university degree programs. Med Sci Educ 30:1137-1144. https://doi. org/10.1007/s40670-020-01026-8

Publisher's note Springer Nature remains neutral with regard to jurisdictional claims in published maps and institutional affiliations. 